\title{
Шлычкова Д.Ю. \\ Уголовно-правовые запреты, направленные на охрану половой неприкосновенности несовершеннолетних, нуждаются в совершенствовании
}

ФГКОУ ВО Университет прокуратуры Российской Федераџии (Россия, Москва)

doi: $10.18411 /$ sr-10-06-2021-35

Организация Объединенных Наций во Всеобщей декларации прав человека провозгласила, что дети имеют право на особую заботу и помощь. Это положение имеет самое прямое отношение к половой свободе и половой неприкосновенности несовершеннолетних. Конвенция о правах ребенка 1989 года подчеркивает, что «государства-участники обязуются защищать ребенка от всех форм сексуальной эксплуатации и сексуального совращения» [1].

Российская Федерация на национальном уровне обеспечивает защиту прав несовершеннолетних от посягательства на половую свободу и половую неприкосновенность последних. Так, статья 38 Конституции Российской Федерации закрепляет защиту государством материнства, детства и семьи. В части защиты несовершеннолетних от преступных посягательств основным регулятором выступает Уголовный кодекс Российской Федерации.

За совершение значительного массива преступлений российским законодателем выделяется отдельный квалифицированный состав, в котором потерпевшим выступает несовершеннолетний. Уголовная ответственность за совершение преступлений по квалифицированным составам в отношении несовершеннолетних, разумеется, усиливается. Так, например, ужесточена уголовная ответственность за доведение до самоубийства несовершеннолетнего (п. «а» ч. 2 ст. 110 УК РФ), истязание (п. «Г» ч. 2 ст. 117 УК РФ), сбыт наркотиков несовершеннолетнему (п. «в» ч. 4 ст. 228.1 УК РФ) и т.д. Современные тенденции российской уголовной политики демонстрируют усиление защиты жизни, здоровья, половой неприкосновенности детей. Так, Федеральным законом от 07.07.2017 № 120-Ф3 были криминализированы склонение к совершению самоубийства или содействие совершению самоубийства (ст. 110.1 УК РФ), а также организация деятельности, направленной на побуждение к совершению самоубийства (ст. 110.2 УК РФ).

Кроме того, совершение преступления в отношении малолетнего является отягчающим обстоятельством, равно как и совершение преступления в отношении несовершеннолетнего родителем или иным лицом, на которое законом возложены обязанности по воспитанию несовершеннолетнего (ст. 63 УК РФ).

Отдельно законодателем подчеркивается тяжесть преступлений против половой свободы и половой неприкосновенности несовершеннолетних. Это отражено в таких статьях Общей части УК РФ, как ст. 73 «Условное осуждение», закрепляющей, что таковое не назначается осужденным за преступления против половой неприкосновенности несовершеннолетних, не достигших четырнадцатилетнего возраста, наряду с лицами, осужденными за преступления террористической направленности. Статья 79 УК РФ устанавливает особые условия условно-досрочного освобождения от наказания осужденных за совершение преступлений против половой неприкосновенности несовершеннолетних. Аналогичные правила действуют при замене неотбытой части наказания более мягким видом наказания для осужденных рассматриваемой категории. Не представляется таким лицам и отсрочка от отбывания наказания.

Вышесказанное свидетельствует о том, что защита несовершеннолетних от преступных посягательств на половую неприкосновенность находится под особым контролем со стороны государства; на лиц, совершивших такие посягательства, не 
распространяется существенный ряд «поблажек», предусмотренных Общей частью УК РФ.

Однако данной тенденции противоречит одно важнейшее обстоятельство: отнесение «развратных действий» (ст. 135 УК РФ) к преступлениям небольшой тяжести. Вопрос, что есть «развратные действия», а что - «иные действия сексуального характера» продолжительное время обсуждается в юридической литературе. Поводом для обсуждений стала неопределенность термина «иные действия сексуального характера» в названии статьи 134 УК РФ и ограничением этого термина мужеложством и лесбиянством в диспозиции названной статьи (ч. 2).

Прокурорско-следственная и судебная практика пошла по пути квалификации оральных соитий с несовершеннолетними, анальных соитий с девушками младше шестнадцати лет по статье «Развратные действия» (ст. 135 УК РФ). Таким образом, получается, что оральные и анальные (в отношении девочек) коитусы - есть преступления небольшой тяжести, за совершение которых априори возможно назначение наказания, не связанного с лишением свободы.

С данным положением сложно согласиться, так как оно несопоставимо с общей концепцией правовой защиты несовершеннолетних от преступных посягательств на половую неприкосновенность.

Отдельного внимания заслуживает разграничение таких действий, как мужеложство, выраженное в анальном коитусе между лицами мужского пола, и развратные действия, выраженные в оральном коитусе между лицами мужского пола. Так, в ст. 134 УК РФ часть первая, предусматривающая уголовную ответственность за естественное половое сношение, отнесена законодателем к преступлению средней тяжести. Однополые контакты (мужеложство и лесбиянство), ответственность за которые предусмотрена ч. 2 ст. 134 УК РФ, уже являются тяжким преступлением (данное разграничение категорий было введено Федеральным законом от 29.02.2012 № 14-Ф3 "О внесении изменений в Уголовный кодекс Российской Федерации и отдельные законодательные акты Российской Федерации в целях усиления ответственности за преступления сексуального характера, совершенные в отношении несовершеннолетних").

Таким образом, уголовная ответственность за гомосексуальные контакты с несовершеннолетними законодателем ужесточена. При этом, под мужеложством понимаются только «действия сексуального характера путем сношения мужчины с мужчиной, введения полового члена активного партнера в анальное отверстие (прямую кишку) пассивного партнера».[2] Оральные же сношения остаются за чертой рассматриваемого понятия. Они подлежат квалификации по статье «Развратные действия» и тем самым относятся к категории преступлений небольшой тяжести. Такое разделение едва ли можно признать оправданным. Известный австрийский основоположник психоанализа 3. Фрейд в труде «Очерки по психологии сексуальности», размышляя о природе отклонений сексуального предпочтения (перверсиях), описывал концепцию, в соответствии с которой «у большинства инвертированных можно выявить подействовавшее в раннем периоде жизни эмоциональное сексуальное впечатление, длительным последствием которого оказывается гомосексуальная склонность». [3]

Можно предположить, что оральный коитус, совершенный с мальчиком мужчиной, есть то самое яркое детское впечатление, последствием которого может стать расстройство сексуального предпочтения. Как уже было сказано, ответственность за гомосексуальные связи после 2012 года с одной стороны ужесточена, с другой стороны - такое ужесточение не распространяется на некоторые виды однополых сексуальных контактов. Кроме того, в настоящее время «неучтенные» способы однополого сексуального удовлетворения продолжают относится к преступлениям небольшой тяжести. 
Указанное обстоятельство нарушает права не просто потерпевших, a потерпевших самой социально незащищенной категории - несовершеннолетних. На мой взгляд, необходимо внести в Уголовный Кодекс Российской Федерации изменения, исключающие неопределенность термина «иные действия сексуального характера» и ужесточающие уголовную ответственность за совершение преступлений против половой неприкосновенности будущего поколения.

$$
* * *
$$

1. "Конвенция о правах ребенка" (одобрена Генеральной Ассамблеей ООН 20.11.1989) (вступила в силу для СССР 15.09.1990)

2. "Комментарий к Уголовному кодексу Российской Федерации. В 4 т. Особенная часть. Разделы VII - VIII" (постатейный) (том 2) (отв. ред. В.М. Лебедев) ("Юрайт", 2017)

3. Фрейд 3. Очерки по психологии сексуальности/Зигмунд Фрейд; пер. с нем. А. Вяхирева, И. Полякова. - СПб: Азбука, Азбука-Аттикус, 2019 - 11 с. 